\title{
Designing and Biological Evaluation of New Benzimidazole Compounds
}

\author{
CH. SRIDEVI*, M. MARI KANNAN, G. ABHINAYANI and N. SRAVYA \\ Department of Pharmaceutical Chemistry, Geethanjali College of Pharmacy, Cheeryal(V), \\ Keesara(M), Hyderabad.501301, A.P, India \\ sridevi.phd@gmail.com
}

Received 30 October 2012 / Accepted 12 November 2012

\begin{abstract}
Benzimidazole derivatives play important role in medical field with many important properties. The potency of these clinically useful drugs in the treatment of bacterial infections and other activities encouraged the development of some more potent and significant compounds. This research article is summarized to know about the chemistry of different derivatives of substituted benzimidazoles along with their pharmacological activities. In the present research the new benzimidazole derivatives were synthesized. The reaction was carried out by condensing $o$-phenylene diamine with carboxylic acid by using Phillip's condensation. The free $\mathrm{N}-\mathrm{H}$ group in benzimidazole was allowed for acetylation. The acetylated product was made to react with different aromatic aldehydes in the presence of alkali to give different chalcones (III A-III F) by aldol condensation. The compounds were synthesized in good yield and their structures were confirmed by M.P, TLC and spectral data. All the synthesized compounds were screened for their antibacterial activity.
\end{abstract}

Keywords: Benzimidazole, $o$-Phenylene diamine, Aromatic aldehydes, Chalcones, Antibacterial activity

\section{Introduction}

Benzimidazole is a heterocyclic compound consists of benzene ring fused with imidazole ring. The chemistry and pharmacology of benzimidazoles have been of great interest to medicinal chemistry, because its derivatives possessed various pharmacological activites ${ }^{1-5}$ such as anticancer, antihypertensive, anthelmenthic, anti-protozoal, antimicrobial, antioxidant, anti-inflammatory, analgesic and anti-hepatitis-B-virus. Moreover benzimidazoles are important intermediates in organic reaction. In the view of above facts, it was contemplated to design and synthesize new chalcones from benzimidazole moiety (SchemeII) using different aromatic aldehydes. All the synthesized compounds were screened for their antibacterial activity. The structures of chalcones were characterised by physical and spectral data.

\section{Experimental}

The melting point of the compounds was determined on a Thoshniwal electric melting point apparatus and the values were uncorrected. IR spectra of the compounds were recorded on a 
Thermo Nicolet Nexus670-FTIR, IICT, and Hyderabad using $\mathrm{KBr}$ disc method. ${ }^{1} \mathrm{H}$ NMR spectra were recorded onAvance-300, IICT, Hyderabad using $\mathrm{CDCl}_{3}$ as solvent. Mass spectra were recorded on HIT ACHI RMU GL, IICT and Hyderabad. All the solvents used were of analytical grade.

\section{General procedure for preparation of benzimidazole ${ }^{6}$ (Phillip's condensation)}

Benzimidazole (II) was synthesized in good yields by condensing $0.01 \mathrm{M}$ of $o$-phenylene diamine, (I) with $0.01 \mathrm{M}$ formic acid in $15 \mathrm{~mL}$ of ethanol for $30 \mathrm{~min}$. The product (II) was dried and recrystallized with absolute alcohol.

\section{General procedure for acetylating benzimidazole $e^{7,8}$ (IIA)}

Mixture of $0.01 \mathrm{M}$ of (II) and $0.01 \mathrm{M}$ of chloroacetone were taken into a $250 \mathrm{~mL}$ round bottom flask. $150 \mathrm{~mL}$ of dry acetone and $30 \mathrm{~g}$ of anhydrous potassium carbonate was added and the reaction mixture was refluxed for $6 \mathrm{~h}$ at $75{ }^{\circ} \mathrm{C}$. Filtrate obtained was concentrated under vacuum. The product (IIA) was dried and recrystallized from acetone. The purity of the compound was checked by TLC and melting point.

\section{1-(1H-Benzo[d]imidazol-1-yl)propan-2-one (IIA)}

Yield: $82 \%$, m.p: $125^{\circ} \mathrm{C}, \mathrm{R}_{\mathrm{f}}$ value: 0.68, IR KBr: 1477.77, 1620.00, 1386.23, $2874.95 \mathrm{~cm}^{-1}$. ${ }^{1} \mathrm{H}$ NMR ( $\left.\mathrm{CDCl}_{3} / \mathrm{TMS}\right)$ (ppm): $2.08\left(\mathrm{~s}, 3 \mathrm{H},-\mathrm{CH}_{3}\right), 7.20-8.80$ (m, 5H, benzimidazole), 4.90 (s, 2H, -methylene). Mass (m/z): $175.1\left(\mathrm{M}^{+}\right)$.

\section{General procedure for preparation of chalcones ${ }^{9,10}$ (IIIA-IIIF)}

Aldol condensation was carried out by following method. A solution of $\mathrm{NaOH} / \mathrm{KOH}(8 \mathrm{~mL}$, $10 \%$ in water) was added drop wise to a well stirred solution of $0.01 \mathrm{M}$ of (IIA) and $0.01 \mathrm{M}$ of different aromatic benzaldehydes in $20 \mathrm{~mL}$ ethanol at cold temperature. The reaction mixture was stirred for $24 \mathrm{~h}$ in ice bath. The reaction was monitored by TLC. Then diluted with ice water and acidified with conc.HCl. Filtered the product and dried. The product was recrystallized with aqueous ethanol. The purity of the compound (IIIA-IIIF) was checked by TLC and melting point. Physical data are shown in Table 1 . Structures of chalcones were characterized by spectral data.

Table 1. Physical data for synthesized compounds

\begin{tabular}{cccccc}
\hline S.No & Compd. & Molecular formula & M. $\mathrm{P},{ }^{0} \mathrm{C}$ & Yield, \% & $\mathrm{R}_{\mathrm{f}}$ value \\
\hline 1. & IIIA & $\mathrm{C}_{17} \mathrm{H}_{14} \mathrm{~N}_{2} \mathrm{O}$ & $123-124$ & 77 & 0.80 \\
2. & IIIB & $\mathrm{C}_{17} \mathrm{H}_{15} \mathrm{~N}_{3} \mathrm{O}$ & $120-122$ & 74 & 0.87 \\
3. & IIIC & $\mathrm{C}_{18} \mathrm{H}_{16} \mathrm{~N}_{2} \mathrm{O}_{2}$ & $120-121$ & 78 & 0.82 \\
4. & IIID & $\mathrm{C}_{17} \mathrm{H}_{13} \mathrm{ClN}_{2} \mathrm{O}$ & $132-135$ & 80 & 0.90 \\
5. & IIIE & $\mathrm{C}_{17} \mathrm{H}_{13} \mathrm{~N}_{3} \mathrm{O}_{3}$ & $135-136$ & 84 & 0.94 \\
6. & IIIF & $\mathrm{C}_{17} \mathrm{H}_{14} \mathrm{~N}_{2} \mathrm{O}_{2}$ & $123-124$ & 72 & 0.88 \\
\hline
\end{tabular}

(E)-1-(1H-Benzo[d]imidazol-1-yl)-4-phenylbut-3-en-2-one (IIIA)

Yield: 77\%; m.p: $123-124{ }^{0} \mathrm{C}$; $\mathrm{R}_{\mathrm{f}}$ value: 0.80; IR KBr: 1669, 1710, 1632, $1320 \mathrm{~cm}^{-1}$; ${ }^{1} \mathrm{H}$ NMR (CDCl 3 / TMS) (ppm): 7.20-7.30 (m, 5H, phenyl), 5.38 (s, 2H, -N- $* \mathrm{CH}_{2}-\mathrm{CO}-$ ), 6.6, 7.5(d, 2H, ethylene), 7.00-8.00 (m, 5H, benzimidazole); Mass (m/z) : $262.6\left(\mathrm{M}^{+}\right)$. 


\section{(E)-1-(1H-Benzo[d]imidazol-1-yl)-4-(4-aminophenyl)but-3-en-2-one (IIIB)}

Yield: $74 \%$; m.p: $128-132{ }^{0} \mathrm{C}$; $\mathrm{R}_{\mathrm{f}}$ value: 0.92 ; IR $\mathrm{KBr}: 3300,3080,1280,1778,1668 \mathrm{~cm}^{-1}$; ${ }^{1} \mathrm{H}$ NMR $\left(\mathrm{CDCl}_{3} / \mathrm{TMS}\right)(\mathrm{ppm}): 7.20-8.10$ (m, 5H, benzimidazole), 6.2, 7.50 (d, 2H, ethylene), 5.48 (s, 2H, -N-*CH$\left.{ }_{2}-\mathrm{CO}-\right)$, 6.2,7.20 (m, 4H, $\left.{ }^{*} \mathrm{CH}_{2}-\mathrm{NH}_{2}\right)$; Mass (m/z): $278.3\left(\mathrm{M}^{+}\right)$.

\section{(E)-1-(1H-Benzo[d]imidazol-1-yl)-4-(4-methoxyphenyl)but-3-en-2-one (IIIC)}

Yield: $78 \%$; m.p: $120{ }^{0} \mathrm{C}$; $\mathrm{R}_{\mathrm{f}}$ value: 0.82; IR KBR: 1049, 1668, $1778 \mathrm{~cm}^{-1}$; ${ }^{1} \mathrm{H}$ NMR ( $\left.\mathrm{CDCl}_{3} / \mathrm{TMS}\right)(\mathrm{ppm}): 7.20-8.10\left(\mathrm{~m}, 5 \mathrm{H}\right.$, benzimidazole), $5.40\left(\mathrm{~s}, 2 \mathrm{H},-\mathrm{C}-{ }^{*} \mathrm{CH}_{2}-\mathrm{CO}-\right)$, 6.60, $7.50\left(\mathrm{~d}, 2 \mathrm{H}\right.$, ethylene), $3.73\left(\mathrm{~s}, 3 \mathrm{H}, \mathrm{O}-* \mathrm{CH}_{3}\right), 6.60-7.20\left(\mathrm{~m}, 4 \mathrm{H},{ }^{*} \mathrm{CH}_{4}-\mathrm{OCH}_{3}\right)$; Mass $(\mathrm{m} / \mathrm{z}): 293.2\left(\mathrm{M}^{+}\right)$

(E)-1-(1H-Benzo[d]imidazol-1-yl)-4-(4-chlorophenyl)but-3-en-2-one (IIID)

Yield: $80 \%$; m.p: $132-135{ }^{0} \mathrm{C}$; $\mathrm{R}_{\mathrm{f}}$ value: 0.90; IR KBr: 746, 5.40, 1668, 1778, $1669 \mathrm{~cm}^{-1}$; ${ }^{1} \mathrm{H}$ NMR $\left(\mathrm{CDCl}_{3} / \mathrm{TMS}\right)(\mathrm{ppm}): 7.20-8.10(\mathrm{~m}, 5 \mathrm{H}$, benzimidazole $), 5.40$ (s, $2 \mathrm{H},-\mathrm{C}-* \mathrm{CH}_{2}{ }^{-}$ CO-), 6.60, 7.50 (d, 2H, ethylene), 6.0, $7.2\left(\mathrm{~m}, 4 \mathrm{H},{ }^{*} \mathrm{CH}_{4}-\mathrm{Cl}\right)$; Mass (m/z): 296.6( $\left.\mathrm{M}^{+}\right)$.

\section{(E)-1-(1H-Benzo[d]imidazol-1-yl)-4-(4-nitrophenyl)but-3-en-2-one (IIIE)}

Yield : 84\% ; m.p:135-136 ${ }^{0} \mathrm{C}$; $\mathrm{R}_{\mathrm{f}}$ value : 0.94; IR KBr: 1456, 1668, 1778, $1669 \mathrm{~cm}^{-1}$; ${ }^{1} \mathrm{H}$ NMR $\left(\mathrm{CDCl}_{3} / \mathrm{TMS}\right)(\mathrm{ppm}): 7.20-8.10$ (m, 5H, benzimidazole), 5.40 (s, $2 \mathrm{H},-\mathrm{C}-* \mathrm{CH}_{2}-$ CO-), 6.60,7.50 (d, 2H, ethylene), 7.5-8.1 (m, 4H, $\left.{ }^{*} \mathrm{CH}_{2}-\mathrm{NO}_{2}\right)$; Mass (m/z): 307.8( $\left(\mathrm{M}^{+}\right)$.

\section{(E)-1-(1H-Benzo[d]imidazol-1-yl)-4-(4-hydroxyphenyl)but-3-en-2-one (IIIF)}

Yield : 72\% ; m.p :123-124 ${ }^{0} \mathrm{C}$; $\mathrm{R}_{\mathrm{f}}$ value : 0.88; IR KBr: 3504, 1668, 1778, $1669 \mathrm{~cm}^{-1}$; ${ }^{1} \mathrm{H}$ NMR $\left(\mathrm{CDCl}_{3}\right.$ / TMS) (ppm): 7.20-8.10 (m, 5H, benzimidazole), 5.40 (s, 2H, -C- $* \mathrm{CH}_{2}-\mathrm{CO}-$ ), 6.60,7.50(d, 2H, ethylene), $5.0(\mathrm{~s}, 1 \mathrm{H}, \mathrm{OH}), 6.0-7.5\left(\mathrm{~m}, 4 \mathrm{H},{ }^{*} \mathrm{CH}_{2}-\mathrm{OH}\right) ;$ Mass $(\mathrm{m} / \mathrm{z}): 278.9\left(\mathrm{M}^{+}\right)$.

\section{Biological activity}

Antibacterial activity ${ }^{11}$

The study was assayed by employing the cup plate method ${ }^{12,13}$ by measuring zone of inhibition in $\mathrm{mm}$. The in vitro antibacterial activity was performed with different strains of both gram positive bacteria i.e., Bacillus subtilis, Staphylococcus aureus and gram negative bacteria i.e., Escherichia coli, Pseudomonas aeruginosa. The results were interpreted in terms of diameter $(\mathrm{mm})$ zone of inhibition. In the cup plate method, solutions of the synthesized compounds at a concentration of $250 \mu \mathrm{g} / \mathrm{mL}$ were prepared in DMF. Dimethyl formamide was used as solvent control and nutrient agar was used as culture medium. The sterile nutrient agar medium for antibacterial study was melted and inoculated with 16-18 hours old broth culture at $1 \%$ level. The aseptic conditions used for the inoculation. After the inoculated medium was transferred to sterile Petri dishes it was evenly distributed and allowed for solidification, the cups $(8 \mathrm{~mm}$ diameter) were made by punching into the agar surface into each of these cups $50 \mu \mathrm{L}$ of the test compound/ reference standard, ciprofloxacin was transferred using a micropipette, these plates were incubated at $37{ }^{\circ} \mathrm{C}$ for 16 hours and then the zone of inhibition was measured. The experiment was performed in duplicate and the average diameter of the zones of inhibition was recorded. Ciprofloxacin $(250 \mu \mathrm{g} / \mathrm{mL})$ was used as standard.

\section{Results and Discussion}

The preparation of benzimidazoles involves the Phillip's condensation. The formed benzimidazole is then subjected to acetylation using chloroacetone to give (IIA) shown in Scheme 1. 
<smiles>Nc1ccccc1N</smiles>

(I)<smiles>CCc1ccc2nc[nH]c2c1</smiles>

(II)

(IIA)<smiles>CC(=O)Cn1cnc2ccccc21</smiles>

\section{Scheme 1}

The acetylated product was then converted into chalcones by aldol condensation using various aromatic aldehydes (Scheme 2). The structure of synthesized compounds (IIIAIIIF) was confirmed on the basis of physical data (Table 1) and IR, NMR, Mass spectroscopy. The spectroscopic data of IR, ${ }^{1} \mathrm{H}$ NMR and Mass are in agreement with the structure of synthesized compounds.

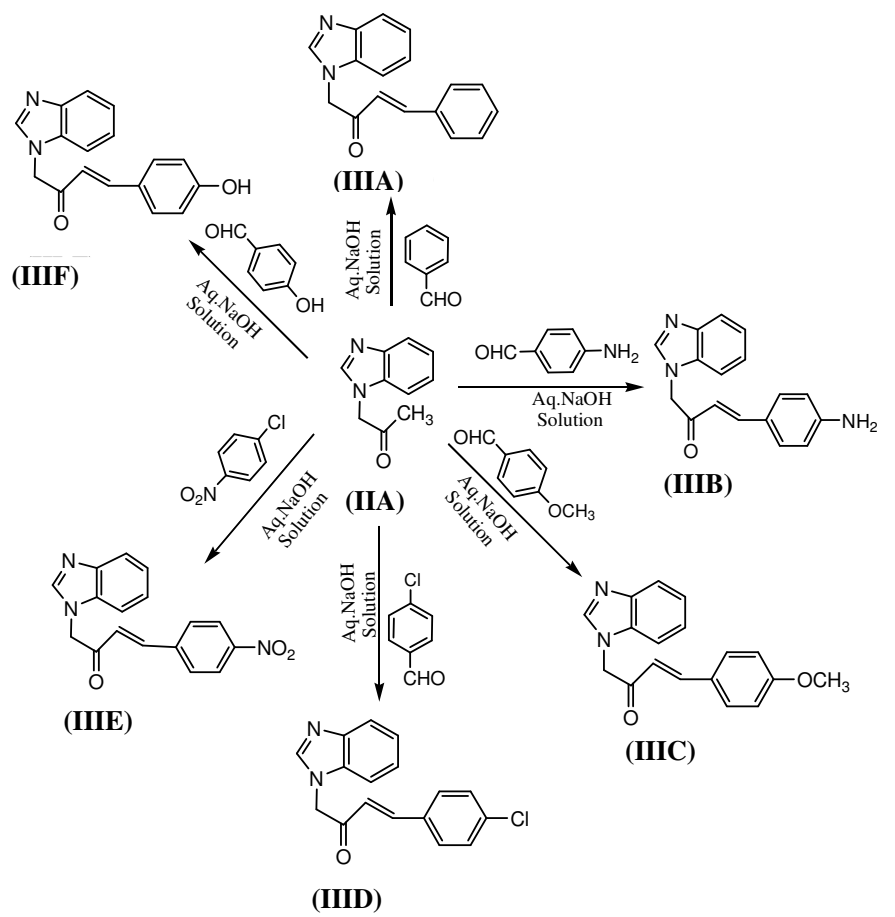

\section{Scheme 2}

The antibacterial activity of the synthesized compounds was summarized in Table 2. The data revealed that all compounds showed little to excellent activity as compared to standard drug ciprofloxacin. Compounds IIIC, IIID and IIIE showed excellent activity against Escherichia coli. Compound IIID has shown excellent activity against Bacillus subtilus. 
Compound IIIE showed good activity against Staphylococcus aureus. Compounds IIIC and IIID showed have shown little activity against Pseudomonas aeruginosa compared to standard drug ciprofloxacin.

Table 2. Antibacterial activity of benzimidazole chalcones derivatives

\begin{tabular}{|c|c|c|c|c|}
\hline \multicolumn{5}{|c|}{ Antibacterial activity [Diameter of the inhibition zone, $\mathrm{mm}$ ] } \\
\hline & $\begin{array}{c}\text { Staphylococcus } \\
\text { aureus }\end{array}$ & $\begin{array}{c}\text { Bacillus } \\
\text { Subtilis }\end{array}$ & E.coli & $\begin{array}{c}\text { Pseudomonas } \\
\text { aeuroginosa }\end{array}$ \\
\hline Control & 0 & 0 & 0 & 0 \\
\hline ciprofloxacin & 19 & 20 & 20 & 19 \\
\hline IIIA & 12 & 11 & 14 & 8 \\
\hline IIIB & 13 & 12 & 14 & 12 \\
\hline IIIC & 17 & 17 & 20 & 16 \\
\hline IIID & 18 & 19 & 19 & 16 \\
\hline IIIE & 19 & 16 & 19 & 14 \\
\hline IIIF & 10 & 12 & 13 & 9 \\
\hline
\end{tabular}

\section{Conclusions}

Using Phillip's condensation benzimidazole was synthesized. It was then acetylated using chloroacetone. The formed acetylated product was subjected to aldol condensation with different aromatic aldehydes to give six different novel benzimidazole chalcones (IIIA-IIIF). Among them the most active compounds IIIC, IIID and IIIE showed excellent activity against Escherichia coli. Compound IIID has shown excellent activity against Bacillus subtilus compared to standard drug ciprofloxacin. All the synthesized compounds were screened for their antibacterial activity. The structures of chalcones were characterized by physical and spectral data.

\section{Acknowledgment}

The authors are thankful to IICT Hyderabad for spectral analysis. Also thankful to Geethanjali College of Pharmacy for providing facilities to carry out this research work.

\section{References}

1. Nakona H, Inova T, Kawasaki N, Miyataka H, Matsumoto H, Taguchi T, Inagabi N, Nagai N and Satosh T, Bio Org Med Chem., 2000, 8(2), 373-380.

2. Sridevi Ch, Balaji K, Naidu A and Sudhakaran R, J Chem Pharma Sci., 2010, 3(1), 13-16.

3. Prakash A and Fauldas D Rabiprazole, Drugs, 1998, 55(2), 261-267.

4. Verdouw P D, Hartog J M, Duncker D J and Saxena R R, J Mol Cell Cardiol., 1986, 18, 73.

5. Sridevi Ch, Balaji K, Naidu A and Sudahakaran R, J Chem., 2010, 7(1), 234-238.

6. Pool W O, Harwood H J and Ralston A W, J Amer Chem Soc., 1937, 59, 178.

7. Leonard J T, Yagnapriya S, Sridhar S K and Gunasekaran V, Indian J Heterocycl Chem., 2005, 14(4), 377-378.

8. Ivashchenko A V and Agafonoica I F, Chem Heterocycl Comp., 1981, 17(2), 184-189.

9. Suthakaran R, Somasekhar G, Sridevi Ch, Mari kannan M, Suganthi K and Nagarajan G, Asian J Chem., 2007, 5, 3353.

10. Sridevi C, Balaji K, Naidu A, Kavimani S, Venkappayya D, Suthakaran R and Parimala S, Int J Pharm Tech Res., 2009, 1(3), 816-821.

11. Mohan J, Goel S and Anupama, Indian J Heterocycl Chem., 2005, 14, 369.

12. Schroeder B O and Jan Wehkamp, Protocol Exchange, 2011.online; DOI:10.1038/protex.2010.204

13. Harinadha Babu V, Sridevi Ch, Joseph A and Srinivasan K K, Indian J Pharm Sci., 2007, 66(8), 470. 